\title{
《西洋比較演劇研究会 例会記録と報告》
}

2011 年度（2011 年 4 月～ 2012 年 3 月）

\section{《第 159 回例会報告》 2011 年 4 月 9 日（成城大学）}

総会

総会では, 例年同様, 前年度の活動と会計報告, 2011 年度活動予定と会計予算, その他として, 今後の会の 運営などが審議され，承認された。

今後の会の運営について議論され, 承認された主なことは, 以下のことである。

I . 研究会体制

研究会体制として，新たに事務局長を置く。

次期運営委員 (カッコ内は役割)

小菅隼人 (代表), 井上優 (庶務), 岩原武則 (記録), 大林のり子, 小田中章浩 (紀要), 斎藤偕子, 萩原健, 小田中章浩 (紀要), 日比野啓 (紀要, Website), 村井華代, 毛利三彌, 森佳子, 安田比呂志 (会計), 山下純 照 (事務局長), 監査 一之瀬正興

II .2011 年度活動計画

例会会場 成城大学を基本とする。

例会日程 4 月 9 日，5月 28 日，6月なし， 7 月 16 日，9/10月，11月なし， 12 月，1月の

6 回を予定。例会内容は事務局長中心に企画。

紀要については, 小田中, 日比野両名の編集責任で電子化の方向で発行。

III .その他

『ベスト・プレイズ』について

『ベスト・プレイズ』（2000 年白鳳社初版発行 $\Rightarrow 2007$ 年相田書房発行）を新訂として, 論創社から出版する。 後期授業開始前に出版予定。

また，『ベスト・ブレイズ』の第二弾の出版も検討する。担当小菅隼人を中心に。

紀要に掲載されている論文の WEB 公開について

今後の紀要の在り方としてのデジタル化 (J-STAGE を利用) の方向で進める。また英文による論文掲載も認め る。J-STAGE とは, 文部科学省所管の独立行政法人科学技術振興機構が運営する電子ジャーナルの無料公開 システム。

紀要編集担当は, 小田中章浩, 日比野啓。紀要公開に関する細部については, 両氏に一任。

FIRT の年次大会について

2011 年 8 月 7 日〜 12 日 (大阪大学) の FIRT の年次大会には当研究会として全面協力。 


\section{新刊書評討論}

\section{斉藤 偕子著『19 世紀アメリカのポピュラー・シアター 国民的アイデンティティの形成』 論創社 2010 年 12 月}

最初に, 斎藤偕子氏から, 著書を書くに至った経緯や出版の意図, そして著書の内容についての報告があつ た。続いて, 報告者常山菜穂子氏と神山彰氏から書評的報告があった。以下はその報告内容の要約である。 最初に, 常山菜穂子氏は, 本書を, アメリカ演劇研究の流れの中でいかに価值あるものか, そしてその位置 づけについて述べた。

「本書は，国民的アイデンティティが確立していった時代と，この「国民」＝「大衆」が主体となって作 り上げたポピュラー・シアターをすり合わせて, 舞台にどのようなアメリカ人気質が移しこまれているか, あるいは，大衆演劇がいかに観客に働きかけて「アメリカ人とは」「アメリカとは」という定義を作るのに 貢献したかを明らかにした試み」であると評価した。

論の展開の特徵は, ひとつの演劇形態を取り上げて, テクストの詳しい翻訳, 上演の状況の詳述や役者の 様子, 時代背景の説明, さらにどのようなアメリカ的特徵が読めるのかを考察するといった手法である。テ クストに密着した方法論を 19 世紀アメリカの大衆演劇に, 即ち, 従来, 文学テクストとしての価值はない とされてきた分野に取り入れることは極めて価值のあることである。また, これは 19 世紀大衆演劇へ光を 当て, 19 世紀演劇のテクストを日本語で翻訳, 紹介した功績, 即ち, 日本におけるアメリカ演劇史の欠落 部分を補って, 演劇史を書き換える作業である。

残念な点は,「アメリカ史の知識を有することを前提に書かれているが故に，副題にある「国民的アイデ ンティティ」は, アメリカの社会背景の解説が不足していることに起因して, それがいかに形成されたのか が分かりにくくなっていること」である。しかし,「それは, 本書の価值を下げる瑕疵ではない。本書のそ こかしこで, これから研究すべき論点・課題も提示されており, さらなる研究発表が待ち遠しい」と締めく くった。

次に, 神山彰氏は, 19 世紀の日本の歴史的事実に目を向け, ポピュラー・シアターという視点で, 日本 の演劇事情とアメリカのものとの比較を試みた。

ポピュラー・シアターは, 安易に「大衆演劇」と訳すことはできない。なぜなら 19 世紀の日本には,「大 衆」や「演劇」という包括的な表現は存在していなかったからである。当時の大衆演劇とは，(女) 剣劇の 事を指していた。

また, ポピュラー・シアターは中産階級が楽しむメロドラマと見世物であったが, なぜ大衆に人気があり, また, なぜ 19 世紀なのかと言えば, それは, 19 世紀は名優の時代であった（々 20 世紀の名優は映画俳優） ことと, リアリズムの時代であったことである。その純粋な意味でのリアリズムは「約束事」なしに分かる という利点を持っていた。

19 世紀のシアターの特徴の一つである「ノスタルジー」は, 日本では新派, 新国劇, 少女歌劇（宝塚） などに存在すると考えられる。また, 19 世紀は視覚優位の時代であるが, 日本でも歌舞伎の中にもパノラ マ的な視覚効果が取り入れられた。この背景には国際博覧会の開催が寄与している。そしてこれらのことが 大劇場化する要因の一つとなった。

国民的アイデンティティの視点では, 日本には国民演劇の存在がある。また, 国民演劇と商業演劇の違い は，前者が理想の観客を，後者は現実の観客を目指していることにある。

フロアーからの多くの発言は, 「19 世紀アメリカのポピュラー・シアターを通しての「アメリカ論」ではあ るが，19 世紀の他の国々の演劇事情を読み手に想起させる著書」に集約できるものであった。

（文責 岩原武則） 


\section{《第 160 回例会報告》 2011 年 5 月 28 日（成城大学）}

\section{〈西洋比較演劇研究 第 10 号〉掲載論文 合評会}

司会 毛利三爾

執筆者 和嶋忠司・北野雅弘・玉垣あゆ・片山幹生・阪本久美子・安田比呂志・森佳子・伊藤愉 (不参加) ・ 江口正登 (不参加)

この合評会は,「研究を発表することの意味を問い直すものとして, 研究者がお互いの論文を読み, 合評 することは有効である」との基本理念から始まった四回目の会である。

基本的な議論の流れとしては，毛利三彌氏の司会のもと，最初に執筆者の論文へのコメントがあり，次に論 文に対し，コメンテーターが質問をし，それに対し，執筆者が答える。さらにフロアーから発言を頂くとい う形式がとられ，最後に毛利三爾氏の総括的発言でまとめられる，という流れであった。

議論された内容も含めて, 執筆者それぞれに, 反省を含めて, まとめていただいたものを, この例会の報告 とする。（また, 諸事情により不参加となった伊藤・江口両名の論文についても若干の議論が行われたので, 両名には, 合評 会の録音データを送り,それをもとに原稿を書いていただいた。)

なお，対象となった論文のタイトルは下記のとおりである。

和嶋忠司：＼cjkstart劇における間の法則ーピンター作品を中心に

北野雅弘：ギリシア悲劇の詩学一カタルシスからポリフォニーヘ

玉垣あゆ：＼cjkstart彼は如何にして神となるのか？

一セネカ「狂えるヘルクレス」における神格化とヘルクレス像について

片山幹生： 13 世紀演劇テクストの流勤性 一 初期フランス語演劇作品と語りものジャンル

阪本久美子： 道化ランスロット・ゴボーは笑えるか? 一マルチェロ・マーニの場合

安田比呂志： 1763 年 5 月 12 日の『リア王』ー18 世紀ロンドンにおける観劇体験に関する一考察

森佳子：オッフェンバックの《にんじん王》初演における「風刺」

一第二帝政と第三共和政の狭間で

伊藤愉：メイエルホリドの演劇空間における音楽的構成と俳優の演技

- 1926 年『査察官』の演出

江口正登：メディアの複数性を考える

ージョン・ジェスランの『ディープ・スリープ』と『ホワイト・ウォーター』 


\section{劇における間の法則 一ピンター作品を中心に}

\section{和嶋 忠司}

本論の副題に「ピンター作品を中心に」と書いたように，この論考はピンターを特徴づける「間」と「沈 黙」をいかに読夕解くかという問題を中心に書かれた。2010 年論文「Turn-taking から劇的対話へ」で参 考としたハーヴィ・サックスらの共同研究『会話の順番取得組織のもっとも簡潔なシステム』を，今回の論 文でも参考にした。

サックスたちの論文は, 日常会話全般について普遍的に働いているテクニックの検討であり, 会話に関わ る人たちが会話を維持するために沈黙をどのように扱うか, そこにどんな規則が働くかということについて の考察を含んでいる。日常会話では, その当事者たちが会話を持続させることを目的として協力しあうこと が大原則となるが, 劇では多くの場合は闘争のモードである。相手に話す機会を与えない(『帰郷』レニーの長 台詞 $)$, 相手の話の腰を折る (同じくレニーに対するルース), 相手の質問を無視する（同じくマックスに対するレニー） など，対話の維持に対してきわめて非協力的である場合が多い。

日常会話では, 発言順番が回ってきたら発言の義務が生じる。劇では, レニーがマックスの質問を無視し たように, 違反が生じる。日常会話ではこういった違反には修復のテクニックの方がクローズアップされる。 したがって単純に日常会話で働くシステムを劇に適用することはできない。そこでヴィマラ・ハーマンは, サックスらの論文とその後の研究を踏まえて, 日常会話理論を劇に適用可能なものにするために慎重に検討 している。今回の論文ではハーマンの考察をピンターに適用した。

私は「間」と「沈黙」の本質的な相違についても考察を進めたかったが，継続と断続という常識的なレべ ルでしか検討できなかった。これら両概念を対立概念としてとらえることが可能なのかどうか, 今後の課題 である。

合評会では，「間」と「沈黙」の基本的な概念設定の不明瞭という根本的な問題を指摘された。「無言」と か「無音」とすべきところに「沈黙」という表記をあてたため, 不可解な論文となってしまったと思う。ま た, 劇テキスト研究の中に演技についての議論が入り込んでいるという問題も指摘された。議論をテキスト 論に限定すべきであったと思う。間の長さを実際に計るのは演技のレベルであるし，ハーマンも俳優による 間の計り方によってその意味が変化することを指摘するように, 間は劇テキストにおける台詞の空白部分で あって, ト書きと同様, 俳優が埋めるべき個所である。敛ましい問題ではあるが, しかし論点がぼけてしまっ たのでは仕方がない。

本論第四節では間の法則を五種類にまとめたが，ごく常識的なレベルではあるものの間と沈黙の識別や間 の分析においては基礎的な指標になると思う。台詞と同様に間にも主語があり，またそれが生じた場所が移 行関連場所 TRP であるかどうかを認定することで, ある程度, 間を台詞と同等に扱えるからである。

ト書きと台詞とのあいだで間と沈黙をどのようにとらえるか，また，この理論を作品解釈にどう生かせるか を今後の課題としたい。 
2011 年「論文合評会を終えて」

ギリシア悲劇の詩学 一カタルシスからポリフォニーへ

北野雅弘

本論文の主要な論点は二つである。第一に，アリストテレス『詩学』における「あわれみとおそれのカタ ルシス」は，感情のカタルシスとしては，その手段を問わず，作品に観客が「あわれみとおそれ」を感じる だけで作動するが, 悲劇は歴史的に「複雑な物語」つまり認知と逆転をつうじての「行動のカタルシス」によつ て両感情を喚起するようになり，その意味でカタルシスはギリシア悲劇の歴史的本質を端的にあらわしてい る。第二に，それにもかかわらず，「カタルシス」はギリシア悲劇を全体として規定するものではなく，エ ウリピデスの後期著作, 特に『オレステス』においては, 別の「詩学」, ポリフォニーが作品を支配している。 カタルシスとポリフォニーは対立する創作原理ないし「詩学」である。カタルシスは作品世界が一つの視点 から評価されることを前提としており，ポリフォニーは「多世界性」によって実現される。ここでの「多世 界性」は，作者ないしその視点を代行する人物のイデオロギー（「計量システム」）が登場人物の様々なイデオ ロギーを評価し，従属させるのではなく，作中に現れる複数のイデオロギーがそれぞれ独自の存在意義と価 值を，作者のイデオロギーに反しても主張し続ける自律性を持つことで実現する。

ポリフォニー演劇としての『オレステス』の特徴は, そこに現れる様々な理念が, 単に解釈史において作 者の声として擁護され続けたという意味で自立性を持つだけでなく, それぞれの理念の内部に他者の声が浸 透し，理念自体の分裂を引き起こしている点にあると論文では主張した。

質問は『オレステス』とポリフォニーに集中した。語り手のいない演劇でバフチンが小説の原理とした多 声性は実現可能なのか，という問い。これは論文の主題そのものでもある。バフチン自身が否定した多声性 を演劇に認めることは演劇の理解にとって有意義であろう。「悲劇」のポリフォニーと言うことが出来るた めには，上演を考慮すべきだが，論文はテキスト分析のレベルに留まっているという問いも出された。この 指摘は的確で, 本論文の弱点である。現在の読者ないし研究者の解釈分裂状況が同時代の観客にも見られた のかは分からない。また，上演は多声的な「戯曲」を一つの声に還元することも戯曲に扔いていきりして いた声の主従関係を逆転することもできる。また，バフチンにおけるポリフォニーは多重人格的分裂を含意 するが，『オレステス』にそれが認められるのか，という問いも重要であった。合評会ではきちんとお答え できなかったが，次のように答えるべきだっただろう。一つの言葉のうちに多様な声を響かせるというポリ フォニー小説的な手法は，反省的な受容が可能な「読書」ではなく時間にしばられた「観劇」においては小 説ほどには有効ではないだろうが，それでも，一人の登場人物の内的な分裂は提示しうるし，それゆえ，多 世界性はジャンルの限界の範囲内ではあるが実現出来ると。 


\section{彼は如何にして神となるのか？ セネカ『狂えるヘルクレス』における神格化とヘルク レス像について}

\section{玉垣あゆ}

今回の論文は本年度提出予定の『セネ力悲劇研究』の一環として制作したものである。私は言葉のつなが りや連想という文学的な観点から, 劇の構成と登場人物たちの人物像, 及びセネカの独自性について, これ まで着目してきた。そして『狂えるへルクレス』には, 冒頭と終幕に関連性が見出され，それはユピテルに よる神格化という要素に係わっていると指摘した。

合評会では主として，二つのご指摘をいただいた。一つは，妻子殺しの罪を負い，隠れ場を探すへルクレ スにとって, 天が身を隠しうる唯一の場所であり, それが神格化に繋がるという考察は, 神格化が持つ肯定 的なイメージにそぐわないのではないか, というものであった。まずこの点について, その後研究を進めた 結果を補足させていただく。

セネ力の『パエドラ』に「私は星々をも亡霊たちをも海をもわが罪によって満たした。これ以外に世界は 残ってはいない。三つの領域が私を知っている」という, 図らずも自らの呪いによって息子を殺すこととなっ たテセウスの台詞が認められる。ここからも察せられるように, セネ力悲劇において, 世界は三つの領域(天, 地下，地上）に分けられて描写される。そして彼とヘルクレスの罪を比すれば, ヘルクレスもまた全世界に 知られていると告げられても不思議はない。しかしセネ力は終幕間際の彼にあえて「私は（地上の）至ると ころで知られている」「そこ（地下）も私を知っている」と発言させたと考慮される。なぜか。今回の論文 では, 天にしか隠れ場がなくユピテルによってそこに迎えられることを意識したためであると論じた。しか しユノーの言にはさらに注目される箇所が認められる。すなわちこの時の天は, ユピテルの情婦とその子た ちによって占められている, というものである。このことから，神格化，すなわち天へ昇るという肯定的な イメージは, 本作品では単純に首肯されうるものではないと言えよう。そればかりか, 彼の神格化は彼の難 業“の成果ゆえというよりもむしろ, ユピテルの庶子ゆえと捉えられかねない描写がなされていると考えら れる。

もう一つのご指摘は「徳（virtus）」について，これはギリシア語のアレテーに相当し身体的なものにあて はまるのであり, 精神的なものはあてはまらないのではないか, というものである。これについては, 元来 「男らしさ」すなわち「武勇」を表すものであった virtus が, ローマ共和制末期頃より精神的なものを含意し, 徐々に後者に重きを置くようになっていったと考えられる。特にセネカについては, 彼の散文においても後 者が重視されると指摘されることから, 本作品における virtusの定義付けを, 彼が一つの主題としたこと は間違いないと言える。

合評会では有意義なご指摘をいただき，博士論文作成に際しても大いに活用させていただいた。また最後 に, ローマ悲劇という馴染みの薄い分野に対し, 貴重な発表の機会を与えて下さったことに深く感謝申し上 げたい。

*ヘルクレスについては「難行」ではなく「難業」が正しいと指導教官小川正廣教授よりご指摘をいただいた。 訂正させていただく。 
2011 年「論文合評会を終えて」

13 世紀演劇テクストの流動性—初期フランス語演劇作品と語りものジャンル

\section{片山 幹生}

13 世紀都市のフランス語演劇は, ジョングルールと呼ばれる芸人が単独で朗唱していた語りものジャン ルの作品を，複数の役者たちによって演じられる対話体のテクストに書き換えることによって成立した。あ らゆる文芸が聴衆を目の前にしてジョングルールによって「演じられていた」この時代，語りものと演劇の ジャンル区分は曖昧なものになっている。今回の論文では, 語りものと演劇ジャンルの間を摇れ動く 13 世 紀の文芸テクストの流動性について，いくつかの実例を挙げて考察した。

合評会ではまず，語りものと演劇テクストで用いられている動詞の時制についての質問があった。語りの 地の文では過去形が, 台詞では現在形が優勢であるが, 中世フランス語のテクストでは, 動詞時制の混乱が よく見られ，時制の違いから，語りの地の文と直接話法の文の文体上の特徴を見出すことは難しい。

また初期演劇作品を表すのに用いられていたジャンル名称についての質問があった。中世には《theatre(あ るいはそのラテン語形 theatrum)»という語はジャンル名称として用いられていなかった。古いフランス語演劇 作品を示すのに，ラテン語の 《 jocus»に由来するフランス語 《jeu»がしばしば用いられるが, 中世の用例 でこの語が演劇ジャンルを示す語として用いられているのは, 13 世紀のアラス出身の作者によって書かれ た劇作品を記録する一写本のみである。これは 13 世紀演劇がアラスという町に限定された地域的な文化現 象であった可能性を示唆している。中世における演劇ジャンルに関わる語彙については, また改めてより詳 細な調査を行いたい。

『13 世紀演劇テクストの流動性』という論文タイトルが, 13 世紀に確固たる演劇ジャンルが既に存在し, そのジャンルに属するテクストが他のジャンルに変形されていったという印象を与えるという指摘もあっ た。タイトルについては確かに指摘の通り, 論文の内容との齟䶣があったように思う。論文では第一に, 複 数の人物によって演じられる演劇作品の母胎として, ジョングルールの一人語りによる語りもの文芸の伝 統があったという仮説に基づき，中世フランスにおける演劇の誕生について言及している。そして第二に， 13 世紀には, アラスで登場した複数の人物による演劇が, 旧来からある語りもの文芸と共存しており, い くつかのテクストには, 語りものと演劇の間の双方的な流動性がみられることを指摘した。語りものから演 劇ジャンルが誕生したことと, 十三世紀においてこの両ジャンルにおいて双方向的な流動性があったことと いう二つの論点が未整理のまま提示されていたことが, 論旨を不明確なものにしてしまったことを反省した w。

13 世紀の演劇ジャンルは, ジョングルールによる語りものジャンルと未分化の状態にあり, そのテクス トにはさまざまな語りもの文芸の痕跡がみられる。これは必ずしも演劇の未発達の段階を示すものではなく， 13 世紀文芸に特有の上演芸術のあり方として肯定的に捉えていきたい。今後は各テクスト, 写本の異本に 含まれる語りの要素の分析を進めることで, 作品のパフォーマンスの状況や創作原理について新たな解釈の 可能性を提示したいと考えている。 


\section{阪本久美子}

合評会では, 文学研究の枠組みの中におけるシェイクスピア上演の研究とは異なった視点から, 演劇研究 に携われている方々のご意見を頂戴でき, 非常に有益であった。その後の考察の結果, 以下のと抢り返答を まとめたい。

(1)ビデオ映像の分析という方法について

見る機会のなかった上演のビデオ映像を分析するという方法に関して批判を受けた。大まかに言うと，上 演研究には二つのアプローチがあるが, 通常の批評は, 上演の時間とスペースに縛られた性質故に, 「印象的」, 印象に頼ったものであるという批判を受けることがある。一方，客観性を重視するとなると，観客へのアン ケートを統計的に解析したものなどで，こちらも是非が問われるアプローチである。前者の弱点を補うため に, 方法論の探求の道程で, 何度も同じ場面のビデオを閲覧して, メモを取り, 何が起こったかを細かに把 握した上で，テクストと照り合わせて分析するという手法を用いてみた。

この実験的アプローチに関して，実際に臨場した場合とは異なるはずだというご意見もあろう。拙論では 道化の演技, 演じ方を論じているため, 役者側の努力, または観客という受容側に対する生産側の努力に焦 点を絞り, コメディの構造を探るとことを目的とした。また, 結果として明確になったコメディの構造から 出発し, 生産側と受容側のコミュニケーションの結果, 受容される際の屈折へと研究を進めたいと考える。

\section{(2)台詞と演技の関係について}

シェイクスピアの道化を演じるにあたっては，現代と異なった言葉の不明確さ，それにも関わらず笑いを 再生しなければならないというプレッシャーから，身体的コメディに依存したり，現代のジョークを挿入し たりする傾向がある。拙論においても，結局は道化の台詞自体は笑いを誘発できないと論じているようだと いうご意見をいただいた。しかしながら，拙論においては，マーニがいかに見事にシェイクスピアの台詞を 身体的に膨らませているかを証明したかった。つまり, 台詞からの逸脱ではなく, 台詞に喚起されるイメー ジや動きが, 身体化 (身体的に具現化) されていると考える。もう少し, この点を前面に押し出して, 明確に 論じるべきであったと思う。

(3)劇全体とコミック・シーンの関係について

マーニの面白さが，劇全体ではどのような効果を及ぼしたかという質問をいただいた。ここで，シェイク スピアの道化を探るうちに，劇を全体的に論じるという観点から遠のいていたことに気がついた。

戯曲の直線的なナレイティヴから捕らえると，道化は明らかに浮いている。現代劇に扔いては，このよう な逸脱は通常ありえない。近年研究が進んでいるシェイクスピアの時代の劇作法によると, 上演台本は複数 の手による可能性が高い。つまり, 現存している二つ折本や四つ折本には, 道化役者, ウィル・ケンプやロバー ト・アーミンによる台詞が含まれているかもしれない。ハムレットの道化役者批判にあるとおり，ケンプは 与えられた台詞から逸脱して, 自分のコミック・シーンを盛り上げた役者だったと思われる。よって, シェ イクスピアの道化を劇全体から捉えることが必要かどうかという疑問が生じる。道化または道化のもたらす 笑いが劇全体にどのような効果を与えるかということも当然論じられるが, 道化の場面をひとつのコミック・ シーンとして分析することも意義があると考える。 


\section{3 年 5 月 12 日の『リア王』ー18 世紀ロンドンの観劇体験に関する一考察}

\section{安田比呂志}

18 世紀イギリスの劇場では,一晚の演目として, 五幕物の悲劇か喜劇をメインピースとして上演した後に, 笑劇やパントマイムなどをアフターピースとして上演していた。当時の観客の観劇体験はこれら二作の観劇 によって完結していたのであり, 劇場における一晚の観劇体験の様相を知るためには, これらの上演が観客 にどのような総合的な体験を与えていたのかを知ることが必要になる。それにもかかわらず，現在の上演史 研究では, 特にメインピースとして上演される作品の個別の研究が中心であり, アフターピースに関する研 究はほとんどなされていない。そこで本論では, メインピースとアフターピースの同時的な研究の有効性や 必要性を示すことを目的とし, その実例として, 1763 年 5 月 12 日にドルリー・レイン劇場で上演された『リ ア王』と『ポリー・ハニコム』を取り上げて論じている。

ジョージ・コールマンの笑劇『ポリー・ハニコム』は, 当時の感傷小説の流行が生み出す弊害を滑稽かつ 巧妙に描き出す笑劇であるが，この笑劇は，興味深いことに，デイヴィッド・ギャリックが上演した『リア 王』と密接な関連性を持っている。ネイハム・テイトの改作に基づく彼の『リア王』には，コーデリアとエ ドガーの恋愛と結婚が描き出されているが，この笑劇が浮き彫りにする恋愛観や結婚観は，そのまま，コー デリアとエドガーの恋愛と結婚を歓迎した当時の観客の反応の様相を明らかにすると同時に，ギャリックが シェイクスピアの原作に立ち返ることをせずにテイトの改作にこだわっていた理由の一端をも浮き彫りにす ることになるからである。

合評会においては，本論の目的である，笑劇そのものに対する研究の有効性や必要性を明らかにしている という点ではさほどの問題は認められなかったようであるが，その一方で，「観劇体験」というものの個別 性や具体性に関する更なる分析や考察の必要性が指摘された。

たとえば, 当時の劇場でハーフプライスという制度が採用されていた事実は, そのまま, 観客全員が決し てプログラムの最初から最後まで劇場にいた訳ではなく, 観客の観劇体験がメインピースとアフターピース の観劇の総合的な体験であるとは一概には言い切れないことを示している。更には, 上演の途中から劇場に 入る観客がどこまで作品世界に「全的に没入していた」のかどうかという疑問もまた, 当時の観客の観劇態 度全般に関わる問題とともに，検証する必要性が指摘された。

また，論文では恋愛観や結婚観を共有する組合せとして『リア王』と『ポリー・ハニコム』が取り上げら れているが, なんらかのテーマに則った演目の選択が毎日行われていたのかという疑問もあがった。配役の 問題も含め, メインピースとアフターピースの組み合わせや, 関連性に関する更なる検証や分析の必要性が 明らかにされた。

今回の合評会を通して,「観劇体験」を扱う際に考える必要のある様々な観点に関して非常に有益な示唆 を多数いただいた。深く感謝申し上げたい。 


\section{オッフェンバックの《にんじん王》初演における風刺—第二帝政と第三共和政の狭間で}

\section{森 佳子}

本論文においては，ジャック・オッフェンバック（1819-1880）のオペレッタのうち普仏戦争（1870 年）以 後に創作された「オペレット・フェリー」と呼ばれる作品群から, 第一作《にんじん王》(1872 年, 台本サル ドゥ）に焦点をあて，それに見られる風刺の価值と意義について明らかにすることを目的としている。

この《にんじん王》を含む四つの「オペレット・フェリー」は，19 世紀に大流行した庶民的な音楽劇で ある「フェリー」(夢幻劇) というジャンルと，オペレッタを融合したものであると言われる。しかしこれ らは一般に,「オッフェンバックのピークが過ぎた頃の作品」という評価を受けており, 筆者にはそうした 偏見を取り除こうという意図があった。なぜ《にんじん王》を選択したかと言えば，それがちょうど第二帝 政から第三共和政への移行期に創作, 上演され, 社会情勢に伴う風刺の変化を見ることが出来ると推測した ためである。

《にんじん王》に残されている当時の批評, 二つの印刷台本, ヴォーカルスコアを考察すると, その政治 的風刺はすでに予見されていた未来に対するものであったが, 事態は予想を越えて進んでしまい, 作者たち は何度も変更を余儀なくされたと推察される。それに加えて,「フェリー」という形式が時代に相応しくな いと考えた音楽評論家とそれを望んだ「大衆」との間にも, ある種の乘離が存在し, それらが作品の評価を 混乱させたのではないかと思われる。また, 上演の途中でカットや変更が行われた背景には, 戦争等によっ て立場がさまざまに変化してしまった観客層を考慮し, 万人に好まれるように工夫を重ねた作者側の意図も 窺われる。

今回の合評会においておそらく数人の方が，「この作品の価值」について言い尽くされていないと感じた ようなので, 補足しておこう。上演中にカットや変更を行ったにもかかわらず, この作品における風刺の価 值は決して弱まった訳ではない。しかしその風刺は, 多くのフランス人が好む「フェリー」の形式によって「曖 昧」にはされている。すなわち妖精や魔法使い, 擬人化された野菜や虫たちの介入による, 幻想というオブ ラートに包まれた「イロニー」がこの作品の本質なのである。まさにそこではオッフェンバックが常々憧れ ていた，原作者E.T.A. ホフマンの世界が描き出されていると言えるだろう。

また, この作品が「なぜこれまで評価されなかったのか」というご質問も受けた。しかし実際は, 「評価 されなかった」訳ではなく「賛否両論」なのだと思う。もっとも当時の音楽雑誌の酷評に始まる, ジャーナ リズムによるこれまでの扱いが，この作品の評価を不十分にして来たことは確かであろう。

今回の論文を執筆するにあたり, パリで台本, 楽譜, 杂隹誌などの一次資料を収集して来たが, 多岐に渡る それらをまとめることは容易でなく, 若干焦点がぼやけてしまったかもしれない。合評会では, 私が七人中 の最後ということで時間もあまりなかったのだが, それでも有効な助言を頂くことが出来, 問題点を客観的 に整理出来たことは収穫であった。 


\section{「メイエルホリドの演劇空間における音楽的構成と俳優の演技」 一 1926 年『査察官』の演出 補稿}

\section{伊藤 愉}

前号に掲載された拙論について，そこで語られるく音楽 > は比喻にすぎないのではないか，またく音楽 > に基づいてメイエルホリドの『査察官』における舞台空間や俳優の演技が規定されていというが，それはあ くまでリズムやテンポといった点に限定されており，音楽の要素である和声やメロディといった問題は看過 されていたのではないか, とご指摘いただいた。

ごく率直に申し上げれば, 視覚的具象的な演劇空間を「音楽的に構成する」という時点で,「音楽」を比 喻として捉えることは免れ得ない。だがこれは, 拙論にも記したように，ロマン主義から象徴主義の系譜に ある，全体性の代名詞としての「音楽」とは異なる。例えば，コメントにもあった「アンサンブル」も，思 想的な背景はないものの調和している状態を理想とし，音楽的状態に近づくことを目指している点で，後者 の立場にあると考える。対して, 前者の「音楽的に構成する」という場合は, 演出の前提としてあり, 到達 点としてあるわけではない。両者はべクトルの違いでしかないが, その違いは筆者には重要だった。という のも, 拙論のそもそもの目的が, その演出を音楽という観点から説明することにあり, それが「音楽だった」 と説明することにはなかったためだ。以上をふまえた上で，若干の補稿を試みたい。

まずご指摘にあったテンポやリズムといった問題だが, 『査察官』上演に際し, 演出家にとって極めて重 要な用件であったことは確かである。この上演に限らずメイエルホリドは，即興的な演技を高く評価する一 方で,「ウケる」演技に俳優が没頭するあまり場面の進行が妨げられ, 芝居が間延びすることに度々悩まさ れていた。それ故, 時間を律する音楽に進行を委ね, 俳優が場面から逸脱しないよう求めた。この点で, 『査 察官』における音楽は和声やメロディといった要素を重視しない範囲で，あくまで機能的に捉えうる。だが 同時に, 場面によっては台詞のフェルマータの長さは, 俳優および観客が決定するとも演出家は述べている。 台詞に伴う音楽の拍は, 長くも短くもなり，ここから実際の演技は音楽的構造の一要素として位置づけられ た。

また革命以後のメイエルホリドは, コメディア・デラルテの影響から，芝居をいくつかのエピソードに分 割して上演することを好んだ。これが, 総譜という音楽用語と無関係ではないと指摘されることは多いが,『査 察官』の舞台美術はこうした分割的構成を強調するものだった。果たして『查察官』ではエピソードごとに,「フ レスタコフの放蕩」,「市長夫人の欲望」といった主題を持ち, 時としてそれぞれの主題は, 和声的な構成と いうよりは，むしろ対位法的に同居した。拙論で挙げたように，ときに不協和音として響きつつ，然るべき タイミングで解消した。こうした演出を, 音楽の構造から展開したものだと同時代人は理解し, メイエルホ リドもまた意識的に試みていたのである。これは演出家によって音楽構造から意識的に導かれたものでこそ あれ，その逆ではなかったと筆者は考える。

もっとも, 今回の論文で取り上げたのは『査察官』一例に過ぎず, 音楽的構成を説得的に語るには限界があっ たように思う。より具体的な事例をそれぞれの演出作品から抽出し，メイエルホリドの手法を「音楽」から 論じていくことを今後の課題としたい。 
2011 年「論文合評会を終えて」

演劇のポストモダニティとメディウム・スペシフィシティ，そして「感性」の問題

\section{江口正登}

今回の合評会に私は参加することが出来なかったが，当日の録音記録を頂いた。拙論に対してもいくつか のご批判やコメントを頂いたのでここで応答を試みたい。

まず最初の問いは，ジェスランとモダニズムとの関係に関するものであった。拙論の論点の一つは，フィ ルムやヴィデオといった個々のメディウムの固有性に対して, ジェスランが極めて意識的であることを指摘 することにあった。ところで, そうしたメディウム・スペシフィックな思考や制作の態度は, 一般的にはモ ダニズムの特徴であるわけだが, 拙論ではジェスランをポストモダニズムと関連付けて論じている。である ならば, ジェスランとモダニズム, もしくは, メディウム・スペシフィシティとポストモダニズムの関係を, 拙論はどのように考えているのか。打およそこうした趣旨のご指摘であったと思う。

これに対する応答だが，拙論で，ジェスランがフィルムやヴィデオといったメディウムの固有性に意識的 である，と述べているのは，あくまでも，「舞台芸術において利用されるフィルムやヴィデオといったメディ ウムの固有性に意識的である」という意味であることに注意を促しておきたい。つまり，問題とされている メディウムのオーダーにずれがあると思われる。舞台芸術に挄いて, モダニズム的な仕方でメディウム・ス ペシフィシティに固執するならば, その一つの範例は, 恐らく, グロトフスキ的な「貧しい演劇」——衣 装や装置, 照明, 音響といった「非本質的」な要素を排除し, 俳優と観客の共在といった最小要素へと演劇 を還元するという発想——のうなものであるだろう。すなわち, 舞台芸術におけるフィルムやヴィデオ は, それらの用いられ方がメディウム・スペシフィックなものであろうとなかろうと，むしろそれを導入す るという時点で既にモダニズム的な純粋性への希求を「污染」するものと考えるべきではないだろうか。こ うした意味において，フィルムやヴィデオをメディウム・スペシフィックな仕方で用いることは，ジェスラ ンのポストモダニズム性と抵触するものではないと思われる。

また，ジェスランがフィルムやヴィデオを用いるに際して，どのような新しい感性をもってそうしている かの記述がほしい，というご意見や，それらメディアの使用を，より明確に系譜の上に位置づけて論じてほ しい, というご意見も頂いた。これについてはご指摘の通りだと思う。社会的・歴史的なパースペクティヴ の拡がりという意味において, 拙稿に一一致命的な瑕疪ではないとは思うものの一一不十分な点があるの は確かであるだろう。今後の課題としたい。とりわけ，「感性」というものは，相当に厄介であると同時に， 魅惑的, また本質的な問いであると思われる。学術知の名に相応しい実質をもっててれに答えるのは大変な 作業になるだろうが, 研究を継続していく中で, 常に心に留めておきたいと思われた。

最後に, 今回の合評会欠席の非礼をお詫びしつつ, 紀要執筆の機会をいただき, またこのような場を設け て下さった西洋比較演劇研究会の皆様に, 改深く感謝を申し上げたい。ありがとうございました。 


\title{
《第 161 回例会報告》 2011 年 7 月 16 日（成城大学）
}

研究発表 -1

\section{七代目松本幸四郎の演劇写真利用 —“Making Up” の影響による扮装研究を中心に一}

\author{
村島 彩加
}

「生涯に 1700 回以上『钓進帳』の弁慶を演じた役者」として, また, 戦後歌舞伎の牽引者である三人の 名優：十一代目市川団十郎，二代目尾上松緑，初代松本白婯の父として知られる，七代目松本幸四郎（1870 〜 1949）が熱中していた写真術と演技研究の関係性についての研究発表であった。

七代目松本幸四郎が，積極的に演技研究に写真を用いた最初の役者であったこと，また，写真術の習得に関 わる人脈や，海外の演劇写真から得た影響が非常に大きいことに気付かされる。

その成果が最もよく表れているものとして, 明治 40 年代初頭の『演芸画報』に掲載された数枚の研究写 真や，現在では全く省みられることのない，新作・翻訳物における彼の工夫を挙げることが出来る。

彼が八代目市川高麗蔵を名乗っていた明治 30 年代後半から 40 年代に蒐集した海外の演劇写真, 特に彼 が扮装術の研究に用いたとされる演劇書 “Making Up” (James Young, M.WITMARK \& SONS.1905) からの影響を 中心に, 従来ほとんど指摘されなかった幸四郎の翻訳・新作物における工夫とその評価と共に, 彼が積極的 に扮装研究を行っていた明治 40 年前後における「表情」に対する関心の高まりについて検証した。

研究発表 -2

詩人 $=$ 大使ポール・クローデルの『女と影』と 1920 年代の日本

根岸 徹郎

経済，通商問題に通じた外交官として評価の高かったポール・クローデルは，1921 年（大正 10 年） 11 月 に駐日フランス大使として東京に着任，その後 1927 年（昭和 2 年） 2 月まで日本に滞在した（ただし，そのう ちの一年間は休腵で帰国)。そしてその間に，東京日仏会館と関西日仏学館の設立に尽力した。彼は，日本では 当初から外交官としてよりもむしろ文学者としての面に関心が寄せられ, 詩人大使という呼び名が捧げられ た人物である。

その当時, 新たな舞踊を模索していた歌舞伎俳優の中村福助（五世）が率いる羽衣会は, この評判の詩人 大使に注目し, 彼がニジンスキーに触発されてブラジルで書いた作品『男とその欲望』(1917) の上演許可を 求めたが, クローデルは, 日本向けに新たな作品『女と影』(1922) を書き下ろした。この舞踊劇は最終的に 1923 年 3 月, 帝国劇場で羽衣会に松本幸四郎を加えた俳優陣, 杵屋佐吉（四世）の音楽, 鏑木清方の美術 で上演された。しかし，その評判はけっして芳しいものではなく，正宗白鳥などから手厳しい批評が寄せら れた。

発表では, この『女と影』を中心に，この小品がクローデル作品の中で占める位置を考察する同時に， 1920 年代の日本という状況の中で，この上演が持っていた意義と，それに対する人々の反応を検証し，日 本に来たことで生じたと思われるクローデルの意識の変化を視野に入れた上で, 1920 年代という時代の特 色とクローデルの関わりを検証した。 


\section{《第 162 回例会報告》 2011 年 10 月 1 日（成城大学）}

\section{国際演劇学会 2011 （大阪）参加報告ならびに検討会}

報告は総合司会山下純照のもと, 以下の三部構成で行われた。

報告 -1「実行委員の立場から：開催にいたるまで」 小菅隼人・山下純照

「一般発表者の立場から (1)」 萩原健

「ワーキング・グループ参加者の立場から」高橋慎也

討論 $-1 「$ 報告 1 に関して」

報告 -2「New Scholars' Forum 発表の立場から」 江口正登

討論 -2「報告 2 を受けて：国際学会と若手研究者の関わりについて」

報告 -3「一般発表者の立場から（2）

「フィルム・セッション」 小菅隼人

アンドロイド演劇：「平田オリザのカガクする心」日比野啓

「日本の音楽劇」森佳子

「全体を振り返って」毛利三彌・永田靖

討論 -3「IFTR2011 と演劇研究の今後について」

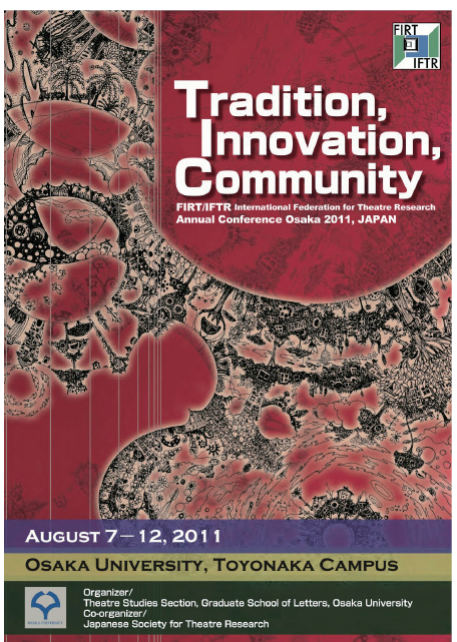

報告は様々な視点で行われたが，紙面の関係上，この例会報告は，「今後参加が見込まれる研究者たちの 国際大会での役立つ経験・体験」という視点を主にまとめることにする。

大会の構成は,「基調講演・一般発表・(テーマ別の) ワーキング・クループ・若手の研究者のフォーラム」 の 4 本柱に, エクスカーション【excursion：小旅行】が付いている。今回は, これに加えてフィルム・セッ ションがあった。

実行委員としては, あらゆる事態を想定し, 適切な組織づくりが求められる。また, 必ず起こるとされる 「想定外」の事態も考慮しておかなければならない。

発表者として, 最大な問題は, 発表言語である英語の問題である。特に, 研究分野が他言語地域の場合, 若干のヒヤリング (聞き取り) の問題がある。また non-native の英語に対する “慣れ” も重要な課題である。 加えて, 議論に加わる “タイミング”を見極める力の養成も必要となる。それらの課題を克服するためには, 「経験」が大切である。その「経験」を積む上で, 西洋比較演劇研究会として, 英語での例会, 紀要におけ る英文での論文掲載などを積極的に考えていかなければならない。また，海外から研究者を呼び，ミニ研究 会などを開催することも「経験」を積むことに寄与するであろう。

発表内容と形式という点では, 20 分の発表と 10 分の討論という一般的な形式では, やはり十分な議論 が交わされない。従って，「ワーキング・グループ」という形式は，今後，このような国際大会の中心とな るべきである。また, 「若手の研究者のフォーラム」は, 今後伸びしろのある形式であろう。今後, 若い研 究者をこのような場に送り, “慣れ”させることも研究会としては重要な仕事である。

IFTR には NEW SCHOLARS' PRIZE があり, 優秀な研究発表のみならず, 研究論文に対しても賞を与え, 奨学金も寄与する制度がある。それらを有効に利用し，国際舞台へ羽ばたく若者の出現を期待する。

日本の演劇のみならず, 己の演劇論を異文化の中で育った他国の演劇研究者へどのように“伝える”かは, 国際大会での日本人研究者にとって今後の大きな課題である。

(文責 岩原武則) 
《第 163 回例会報告》 2011 年 12 月 10 日（成城大学）

研究発表 -1

日本的擬人化の思考と石黒浩のロボット哲学論

\section{曽根雄次}

旧来のシアター・スタディーズの研究対象をこえる文化現象を含むパフォーマンス・スタディーズの観点 から, エンターテーメントとしてのロボット・スペクタクルに注目し, 日本に打けるテクノロジーと人との 関係性を検証する。日本のエンターテーメント・ロボットが，西洋的な「人間」対「機械」「虚」対「実」 という二分法では割り切れない機能性を持つ場合, ジャパニーズ・スタディーズの観点からの新たな理論が 必要であろう。

このような日本の文化的特性を論ずることは, 表象, オブジェ, パフォーマンス, 観客の受容力といった 諸要素が複雑に絡み合う構造に光をあてることを意味し, (西洋における) ロボットとの関係性や, エンター テーメント・スペクタクルの研究一般にも新たな視点をもたらすものである。

発表では, ヒューマノイドとアンドロイドの製作・実験で内外に知られるロボット工学者の大阪大学・石黒 浩教授の研究を取り上げ, 平田オリザ (青年団/大阪大学) との演劇実験を中心に分析を試みた。彼は,「ロボッ トは人間を映す鏡である」との哲学的命題のもとで活動を続けている彼の哲学論に見え隠れするのは，日本 神話，神道，仏教に発する擬人化という文化的背景である。

彼が演劇実験の上でロボットは観客に容認されていた，と説明するとき，日本的擬人化の伝統的思考が彼 の思考の上でどのように再生，再経験されているかなどの点を考察した。

研究発表 -2

\section{中国における影絵人形劇と地方劇}

$$
\text { 山下一夫 }
$$

中国西北部で実施した影絵人形劇の調査をもとに，中国における人形劇と地方劇の関係についての研究発 表である。

中国は全土に様々な種類の影絵人形劇が分布しており, 知られざる「影絵人形劇大国」である。しかし, かつて孫楷第氏と周貽白氏との間に交わされた中国演劇起源論争によって, 影絵人形劇は「曲芸」に類する ものとされて, 演劇研究から切り離され, 研究上の「空白地帯」となっていた。近年, 中国が無形文化遺産 保護政策に乗り出した結果, 影絵人形劇は中国の伝統文化の重要な一脈として注目を浴び, 研究対象となっ たが，それらは起源論争の影響もあって，影絵人形劇を自律的に成立している分野と見なす傾向が強い。 ある地域の影絵人形劇の種類について検討する場合, 他地域の影絵人形劇と比較するよりも，音楽や台本な どの面において多くの共有点を有する，同一地域の地方劇を取り上げた方が有効である。また，決着してい たはずの中国演劇の起源論争も, 近年曾永義氏によって孫楷第氏と周貽白氏の説を止揚し, 起源を多元的に 捉えようとする観点が提出され，その再検討が迫られている状況にある。

発表は, 影絵人形劇と地方劇の関係を経済環境による転換現象とみなし, 両者を統合的に捉えることで, 中国の伝統演劇について新たなパー スペクティブを得るとともに, 諸外国の伝統演劇と比較した場合の共 通性および独自性について検証するものであった。 


\section{《第 164 回例会報告》 2012 年 1 月 21 日（成城大学）}

グローバル化という視点から, 発表・議論を英語で行うという趣旨のもとでの発表であった。

研究発表 -1

\section{Aging Body in Dance: Researching Images of Children and their Perspectives}

\section{Nanako Nakajima}

Due to recent medical advancements, the percentage of elderly people in society has increased dramatically and aging has become a global phenomenon. In addition to the issue of aging population, the issue of aging becomes the emerging theme in the 21 st century. From a demographic point of view, an aging population is produced by two major factors: increased life expectancy and declining fertility rates. The population aging is thus also the result of the decreasing number of children within society.

The idea of childhood is also the product of modern society, following Centuries of Childhood: A Social History of Family Life by Philippe Ariès (1962 [1960]). The image of immaturity is directly related to certain cultural and social expectations. Along with gender, age is a socially constructed difference; however, recent research in cultural studies has been dominated by studies of differences other than age. If we think of aging as a gradual temporal process, then two subjects must be reconsidered: the reexamination of chronological age, and the fundamental value of these socially constructed minorities. Childhood studies help us to avoid the nostalgic illusion and essentialist ideology of children that is projected by adults, while the legal perspective provides an understanding of how one assesses the idea of the child within the modern legal framework, thereby teaching us what makes an individual a child.

In the field of dance, the issue of aging reveals the system and the politics of this art form, which requires the human body to be used as its own medium. In western dance history, the NY postmodern dance during the 1960s and 1970s questioned the category of dance movement. Everyone including amateurs participated in dance, regardless of level of dance training, but neither aged nor child dancers were included. Some recent European performances such as Boris Charmatz's "Enfant”and Gob Squad's "Before Your Very Eyes" both using child performers, question the intersubjectivity and the socially constructed image of children. Infantilism is considered part of the Japanese cultural phenomena. Some contemporary performances are described as “child body" (コドモ身体) brought through the performers' denial or misuse of "normal" preconceived dance techniques. In Japanese dance, professional 70 or 80 year-old dancers are still found, which makes this dance culture very specific. In the case of aging dancers, the lifelong commitment to artistic and personal development makes up for the loss of physical ability and preconceived technique. Thinking along the issue of agency and dance technique developed in the youth-oriented, Euro-Americandominated dance history, this cultural image of infancy demonstrates the Japanese aesthetics of aging body in dance, showing the mirror image of the respected old dancers. 
研究発表 -2

本物と偽物の間を摇れ動く：平田オリザのアンドロイド演劇

\section{日比野啓}

一人の女優と女性の「アンドロイド」が出演する 15 分の短編, 平田オリザの「さようなら」を見て否定 的な感想を抱いた観客に共通するのは「裏切られた」という思いだろう。だが彼らは自らの期待に裏切られ たのだ。正統な芸術作品を期待していったら，テクノロジーを使ったハッタリで，胡散臭い感傷的なドラマ を糊塗するだけのものを見せられたのだから。彼らの困惑は，この「アンドロイド」なる代物が，自力で動 くことはもとより, プログラムをもとにして反応するわけでもない, ということを知ってさらにいや増す。 たしかに発声のタイミングは正確だが, これは予め計算されていたからではなく, 人間の女優が舞台裏で「口 パク」しているだけのことである。この女優によって遠隔操作される「アンドロイド」とは, 見世物小屋で 見かける機械仕掛けの人形とさして変わらない。

この作品が安手のサーカスの余興に近いという印象は舞台装置によって強められる。薄暗い照明はたしか にこの世ならぬ雰囲気を醸し出すのに一役買っているが, 同時にそのせいで女優やアンドロイドの顔の表情 をはじめとして舞台上のすべてのものはぼんやりとはっきりしない。死の床にいる病人を演じる女優は動き 回ることをしないが, それはアンドロイドを動さないためのうまい口実になっている。身振りをするために 動けば, アンドロイドがそれほど人間に似ていないことがわかってしまうからだ。アメリカ人の女優が話す たどたどしい日本語は, アンドロイドの合成された音声とよい対照をなしているが, それはいわば双方の不 自然さが中和するということでもある。こうした「カモフラージュ」効果に気づいてしまうと, 観客は自分 が騙されていると思わずにはいられない。とりわけ，科学の万能性という現代の神話によって，「通常の」 演劇では表象不可能な, 真性で権威のあるものを探し求めることを動機づけられているゆえに。

だがこの「偽物臭さ」を観客に伝えるのは平田の戦略の一部だ。そもそも, アンディ・ウォーホールの『キャ ンベルのスープ畋同様，「さようなら」は平凡なものを下劣な模倣であるとともに，その「フレーミング」 効果によってその平凡なものを特別でかけがえのないものに見せてしまうリアリズム芸術に対する批判であ る。ところが, ウォーホールが「フェイクの」表象から批評的距離をとることを見る者にうながすのに対し, 平田は観客が「フェイクの」表象に感情移入することを望む。批評的距離がないために, 安っぽいシュミラー クラに何ら意味を見いだせずに，平田の作品を否定的に裁断する観客が出てくるのだ。だが平田の意図は別 にある。自らが正統性を与えることができないものにたいして観客が感情移入することを促すことで, 平田 は疎外感と虚無感を観客と共有しようとする。見てくれだけのレプリカに囲まれて, 平田も観客も「本物」 を手に入れることができないのだ。

平田と観客が手に入れられない「本物」のうちでもっとも真性なものは死である。「さようなら」には口 マン主義が大好きな死の欲望のモティーフを組み入れられていることは否定できないが，いま・ここで死め ことができない, ということはそのモティーフをパロディにしている, ということなのだ。人間役は死の床 についていることになっているが, 観客はそれが虚構の死であることを知っている。一方で, 観客がこの作 品を見ているということは, 彼らもまた死から疎外されているのだ。「嘘」の死は到るところにあるが, 本 物はどこにも見いだせない。この内なるロジックに従えば, 平田がアンドロイドを用いたのは, 人間を 取り巻き, そのせいで「本物」に近づけない, 無数の偽物のコピーの比喻としてであると結論づけることは それほど難しいことではない。本発表では, たとえばランボーおよびカール・ブッセの翻訳された詩の引用 と平田の真正性の探究とを関連づけることで, この結論に到るまでの手順を明らかにしたい。

本物と偽物の間を摇れ動く「さようなら」は，両者の間で美的なバランスをとっている。 